International Journal of Eurasia Social Sciences
Vol: 10, Issue: 37, pp. (771-782).

\title{
CONTEMPLATING THE EFFECT OF HODJA AHMED YESEVI ON ISLAMIZATION OF BALKANS FROM PUBLIC DIPLOMACY PERSPECTIVE*
}

\author{
Kadir SANCAK \\ Asst Prof, Gümüşhane University, kadirsancak@gmail.com \\ ORCID: 0000-0001-9266-5592
}

\begin{abstract}
Although only half a century passed since the concept of public diplomacy is started to be used in the literature, it is known that the activities expressed with this concept have been used since ancient times. The main objective of the public diplomacy is to influence other communities. This objective is realized by introducing your own values that you possess to the opposite party through all kinds of legitimate channels. When history is considered in this sense, it may be seen that it is possible to establish a connection between Hodja Ahmed Yesevi's activities and modern public diplomacy. Hodja Ahmed Yesevi, who was a quite significant character in Turkish-Islamic World, was assigned to raise tens of thousands of novices/dervishes and to guide them on Turkistan-based line of east-west, north-east. One of the places that these dervishes, who predominantly went towards west, was Balkan lands. In this era, when Balkan geography was not honored with Islam yet, aforementioned dervishes carried Ahmed Yesevi doctrine to these lands and conduced to introducing the region to Turkish-Islamic culture. On these lands, dervishes established lodges for themselves and communed directly with the society through the bridges and mills they built and through similar activities and serve them. Dervishes, who were raised within this tradition Sarı Saltık being in the first place, set an example to the communities living in these lands with their exemplary behaviors and played a fundamental role in expansion of Islamism. In this document, the activities of the dervishes, who succeeded from Yesevi tradition, were discussed within the perspective, within the context of Islamization of the Balkans will be discussed from the perspective of public diplomacy concept. Similarities and differences between public diplomacy applications, which is a modern concept however, whose application examples may be found since ancient times, and activities of the dervishes will be indicated here. Besides, there is another objective of this study that is to discuss Hodja Yesevi, who is a moral we own, within the context of international relations concepts. Generally, it is not possible to encounter Eastern names frequently in the texts regarding international relations discipline. Consequently, the objective of this study is to humbly contribute to the deficiency in this field.
\end{abstract}

Keywords: Public Diplomacy, Hodja Ahmed Yesevi, Dervishes, Balkans.

\footnotetext{
* This study is the edited version of the paper under the name of "Balkanların İslamlaşmasındaki Hoca Ahmed Yesevî Etkisine Kamu Diplomasisi Perspektifinden Bakmak" in the International Symposium of Hodja Ahmed Yesevi from Past to the Future held in Istanbul on 26-28 September 2016.
} 


\section{INTRODUCTION}

Each state acts primarily for the purpose of maintaining and sustaining her existence. One of the main ways to achieve this is to hold more power. States determines many policies in order to have more power and search for ways to maximize her interests with this determined policies. It is known that through world history states used many political tools and methods in order to afford her desires/interests. It may be observed that during the era approximately until a century ago military methods were generally considered as political tool. However, as the heavy cost of the wars experienced in 20th century on the - winning and/or losing - parties was realized, military methods started to lose their primary position. Due to the fact that economic tools comprise much lower costs with regards to both human beings and financial damages, economy was enabled to be preferred much more as a foreign policy tool with qualifications such as incentives, embargos, sanctions and so forth.

As the Cold War era drew to a close, the concept of soft power, which is another form of power, started to come into prominence. Joseph S. Nye, who is the person brought the concept in the literature, expressed the concept in the simplest way as the effect a country produces on other communities with admiration/attraction arising from the values that country possesses. On the other hand, the communication and interactions between people reached higher dimensions as never before in parallel to the developments experienced in communication technologies and globalization gathered a high speed in this last period of history. Concordantly, access to information and news got easier and this situation conduced to the increase of interest of the public, which is in the governed position, in state government and of the effect of the public on the government. As a natural consequence of this, - on the condition to be more in democratic governments public opinion started to see more value in the presence of decision making mechanisms.

As the public opinion came into prominence in international relationships, methods and tools that are used in international arena started to be redefined accordingly. Public diplomacy activities, which is one of the most effective and appropriate tools in shaping public opinion, became one of the preferred methods in this context.

\section{PUBLIC DIPLOMACY}

Public diplomacy is a concept of modern times however, its history and application examples trace back to the early stages when conflicts between the states started. Moreover, it was during Post-Cold War era when public diplomacy essentially came to prominence within international relationships and became a significant tool of foreign policy. The concept was first brought in the literature in 1965 by Edmund Gullion, who was the dean of Fletcher School of Law and Diplomacy in USA (Yağmurlu, 2007:13).

It is known that there are more than a hundred definitions in the literature with regards to what public diplomacy is (Fitzpatrick, 2010:89) however, it may be observed that similar points are mentioned generally in these definitions. When the common points of the definitions are taken into consideration, it is possible to 
define the concept as the activities of informing and affecting other communities through all kinds of legitimate methods in order to make a nation's ideas, ideals, institutions and culture understood on the purpose of supporting the interests of a state (Pratkanis, 2009:112; Tuch, 1993:3).

As it may be comprehended from the definition, the primary purpose of public diplomacy for a country to introduce and express her cultural values such as language, religion, art, sports and similar values being in the first place and her political and social values to the public of other countries. Once again as expressed in the definition, public diplomacy activities are legitimate activities and have a constructive characteristic; they are not activities based on disinformation as is in black propaganda. While carrying out public diplomacy activities, it is aimed for aforementioned values to generate admiration/contentment/sympathy toward the principal country. In case the activities carried out generate sympathy on the intended population in favor of the country carrying out the activities and in case this sympathy is reflected on the target public opinion, then it means that the public diplomacy activities applied succeeded.

As mentioned before, although they were not named as such, public diplomacy activities have been carried out from time immemorial. On the other hand, performing these activities with corporate institutions traces barely back to the end of 19th century and it is known that the first step regarding the matter was taken by France in the year of 1883 with the establishment of Alliance Francaise (Nye, 2008:96). It may be observed that in 20th century, other great powers that wanted to have a say in global system, England being in the first place, started to be institutionalized in this field.

It is stated in the literature that significant public diplomacy activities were carried out within Turkish history, particularly during Ottoman Empire era. However, transformation of these activities into a state policy and performing the activities through government agencies took place Republican era. The first step of Turkey's institutionalization with a public diplomacy comprehension was taken with the establishment of Turkish Cooperation and Coordination Agency (TIKA) in 1992 (TIKA, 2014:10). On the other hand, main institutionalization that is in accordance with a foreign policy approach whose principles and framework are determined came into existence in the last decade with the establishment of Yunus Emre Institutes (YEE) and similar institutional structures, Coordinatorship of Public Diplomacy.

TiKA, which is one of the main crucial public diplomacy institutions of Turkey, offers services in many different fields in more than hundred and twenty countries. For instance, TiKA makes a huge contribution to Turkey within the context of public diplomacy as an institution that "operates cataract surgeries in Sudan, rushes to help the people when an earthquake occurred in Haiti, carries out restorations of monuments, which are tokens of ancestors, in Macedonia and Egypt, builds schools in Kyrgyzstan, brings water to many people in Africa, and strives to protect mother-child health in Afghanistan." (TiKA, 2014:7).

Another institution that makes significant contributions in the field of public diplomacy is Yunus Emre Institutes (YEE) and these institutes operate affiliated with Yunus Emre Foundation. YEE, which was established to 
promote Turkish Language, culture and art abroad and to offer services to have education in aforementioned fields in general, organizes various activities in order to realize the relevant objective. Apart from teaching Turkish, which is the most important mission of the institute, YEE also promotes Turkish culture with many different activities such as Yunus Emre Oratorio in Astana, jazz concert in Pristine, Necip Fazıl Kısakürek Poetry Contest in London, marbling course in Sarajevo, Mehmet Akif Ersoy Memorial in Cairo, children's theatre in Paris and Hacivat-Karagöz shadow puppetry show in Warsaw (Yediyıldız).

\section{LIFE OF HODJA AHMED YESEVI}

In order to acknowledge significant people, who affected the masses with their ideas and left traces in history, and understand them better it is quite important to know the conditions of the periods aforementioned people lived in. In this context, before discussing Ahmed Yesevi's life, it would be helpful to put forth the geography, social/religious structure and political atmosphere he lived in in order to understand the matter better.

The place Yesevi was born and then lived in is Turkistan geography where Syr Darya, Aral Sea, Yedisu, Issık Lake, south of Celestial Mountains and city of Kaşgar are included (Kencetay, 2012:776). Long before Yesevi was born, Satuk Buğra Khan, who is one of the emperors of Karahanli State, accepted Islam in the middle of 10th Century and acceptance of Islam played an important role in Turks acceptance of Islam in masses. On the other hand, in the 12th century when Yesevi lived in, majority of Turks were not Muslims yet (Kencetay, 2012:777). Karahanlis, who ruled over Transoxiana and surroundings since 9th century, started to lose power in the middle of 11th century and divided into two as east and west. In the year of 1089, Seljukian Sultan Melikşah seized Samarkand and Bukhara, however, Seljukian's hegemony over the region did not last long. To mention briefly, during the 12th century that Yesevi lived in, hegemony struggles were experienced in Turkistan region between Turkish states and political power could not be fully ensured (Kencetay, 2012:778). During this period of political instability, social problems came to exist and moral corruptions arose. As you see, Hodja Ahmed Yesevi tried to guide the public spiritually and ethically with his philosophies in such an environment when society was dealing with many disasters and distresses.

The references with regards to the life of Hodja Ahmed Yesevi are generally legends and his philosophies. Therefore, precise information that historians compromised on with regards to his personality is not available. However, this situation implies another problem and this problem lies beyond the topic of this study. In this study, biography of Hodja Ahmed Yesevi is expressed on the basis of generally accepted data. Hodja Ahmed Yesevi, who lived between the years of 1093?-1166? (Baş, 2011:22), was born in Sayram town that is close to city of Turkistan, which is within the boundaries of Kazakhstan today. At first he went to Yesi and became follower of Arslan Baba and then went to Bukhara and became follower of Sheik Yusuf el-Hemedani. Yesevi, who became the spiritual guide for some time after Hemedani, then returned to Yesi and continues his spiritual guidance showing the true path activities here until he died (Baş, 2011:26,27). 
Although Yesevi, who was quite competent Islamic sciences due to the education he got, knew Arabic and Persian languages, addressed the Turkish communities he lived within in their own language or in other words in Turkish and tried to communicate Islam with poems written in syllabic meter called hikmet (wisdom). What made him different from many Turkish scholars lived before was that he talked and wrote in Turkish and therefore, by courtesy of him. Turkish became a language of science, love and knowledge (Yıldız, 2015:8). Other dervishes, who addressed the society in Turkish and who tried to communicate Islam, lived in Turkistan before Yesevi, (Baş, 2011:25) however, Yesevilik was the first religious dervish lodge established in Central Asian Turkish World. Accordingly, direct or indirect influence of Yesevilik may be observed in all the dervish orders and Islamic mysticism cults established on the geography from Turkistan to Balkans (Yıldırım, 2012:677). Hodja Ahmed Yesevi did not only explained Islam to the society, he also raised thousands of followers. He assigned his followers to serve and communicate Islam after they graduated and rumor has it that he assigned 99 thousands of these followers as his own caliphs and sent them to distant domains up to Balkans. This situation contributed to many non-Muslim towns to graced with Islam and also provided the opportunity for Yesevilik to continue its existence on a wide geography until today (Baş, 2011:30).

\section{YESEVI DERVISHES AND THEIR ACTIVITIES IN THE BALKANS}

Yesevilik, which was born in Turkistan, expanded to geographies of Central Asia, India and Anatolia (Özköse, 2003:257) and some of the dervishes who came to Anatolia continues their movement to the West and reached up to Balkans. Some of the Yesevi dervishes, who played important roles in Islamization of Anatolia and Balkans, directly became followers of Hodja Ahmed Yesevi and although some of them did not have this opportunity, they performed spiritual guidance activities on aforementioned geography as members of Yesevi dervish order/tradition. Distinguished people such as Hacı Bektaş Veli, Sarı Saltık (Saltuk) and Yunus Emre whose monuments and legends came until today also fed from the same source or in other words from Yesevi tradition. Yesevi dervishes, who set out from Turkistan and expanded to Balkans, were generally named Horasan Erenleri (Khorasan Saints) or Alperenler (Fighters) (Demirci, 1994:61).

Khorasan saints, who played a fundamental role in Islamization of Balkan lands, came to this region before Ottoman State was established and produced a facilitative effect in conquest of the region. In fact, Turks' starting to come to Balkan lands dated back to the times centuries before the existence of the dervishes in the region and reached out to Migration of Tribes. It is known that Avars, Kumans (Kipchaks), Patzinaks and many other Turkish tribes came from the north of Black Sea and settled on these lands later on (Çă̆, 2012:128). However, although some of aforementioned tribes preserved the values they had in the meaning of language and culture, a significant majority was assimilated among the Christian constituents in the region and lost their identities in time. Moreover, dervishes who came to Balkans in the 13th century meeting with people - who came to the region centuries ago and who still preserved their culture - sharing the same language and culture produced a facilitative effect on settlement and conversion activities (Bakırcl, Türkan, 2013:159). 
Voluntary dervishes who spread to all parts of Balkan geography, established dervish lodges and zawiyahs (small Islamic monasteries) and settled in these places. Dervish lodges and zawiyahs were generally established in empty and deserted places in rural areas (Barkan, 2002:248) or waterfronts such as streams or similar water sources (Bakırcı, Türkan, 2013:150). Dervishes, who build lodges in deserted places and inhabited these places, engaged in agriculture and animal husbandry with their followers. Aforementioned dervishes made their living by themselves by having a profession and even contributed to their environments in some way on the contrary to today's perception of dervishes, who make their living with others' donations and who do not work at all. Members of Yesevi dervish order took Hodja Ahmed Yesevi as an example and lived their lives like him. Thus, it is also present in the literature that in accordance with the rumors Hodja Ahmed Yesevi divided his day into three parts and carved wooden spoons in one part and earned his living by selling these spoons (Baş, 2011:43).

There is a general consensus that the first Islamization in Balkans started when a Turkmen tribe under the leadership of Sarı Saltık settled in Dobruca in the years of 1263-64 (Ocak, 2011:75). Although there are many legends about Sarı Saltık, who is considered as the spiritual leader (Bice, 2016:247) of conquest of Balkans with this on this sense, sufficient information about him is not available in historical records (Tuğrul, 2014:118). On the other hand, evaluations are carried out that he was a saint performing miracles in one aspect and a war veteran and a heir of jihad tradition on the other (Ocak, 2011:75). It is known that along with hundreds of dervishes who came from Yesevi tradition and whose name reached out to these days, thousands of dervishes contributed to Islamization process, which started with Sarı Saltık, by means of the lodges and zawiyahs they established (Bakırcı, Türkan, 2013:145-159).

As mentioned before, lodges and zawiyahs, which were established in deserted places or waterfronts, played a crucial role in Islamization of Balkans with the multifaceted services they offered. Both town planning and security of these lands made possible by means of these lodges established in deserted areas (Bakırcı, Türkan, 2013:259). Food allowances and clothing support were offered to people in need and accommodation was procured for travelers and guests (Barkan, 2002:260). On the other hand, mills were built alongside the lodges established on waterfronts and therefore, dervishes' daily bread was ensured in one sense, hereby the opportunity to communicate directly with local people was also enabled (Bakırcı, Türkan, 2013:150). In places without water, aforementioned dervishes drilled wells and they both shared their experiences in this field with the locals and they also helped them meeting water needs.

Lodges and zawiyahs, which were sites where dervishes perform and transfer the oral culture they brought from Yesevi Turkistan, (Üçüncü, 2006:220) became science and culture centers where they were established. Dervishes, who communicated Islam to non-Muslims with Yesevi's philosophies and similar expressions, played a crucial role in teaching and generalization of Turkish language as the most important bearers of oral culture (Bakırcl, Türkan, 2013:158). Lodges that also functioned as schools, fulfilled the educational needs of the people living particularly in rural regions. 
Although there was a unity of purpose among dervishes in the meaning of communication Islam, it may be observed that different methods were applied in doing it. Thus, it is known that while some lodges came to prominence with sportive activities such as archery and wrestling, some served the population by acting as small hospitals (Bakırcı, Türkan, 2013:158).

Despite the fact that dervishes embraced lodges and zawiyahs as their sites, this did not mean an anchoritic life for them. They did not have a life that was dependent on others, they had a philosophy of life as to fulfill the needs of others. They did not content themselves with expressing Islam, they also were models for the local population by means of their life styles. Morality and justice of Islam, which was demonstrated with their life styles themselves, had quite a facilitative effect on conquest of Balkans by Ottomans. Non-Muslim population that was tired of their cruel ruler showed a positive approach Islamic Religion, which they saw in dervishes, and did not put up resistance neither during the conquest nor in the period they were subject to Ottoman government. Thus, the fact that they did not attempt to rebel by taking advantage of the chaos environment experienced during the fights for the throne among Yıldırım Bayezid's sons in Interregnum Era between the years of 1402-1413 was considered by the historians as a sign of the appreciation felt for the Ottoman manner of rule. This condition was not observed only in one development, many similar examples were found in many developments, conquest of Salonika and İstanbul (Sancak, 2015:140). In short, aforementioned dervishes captured the hearts before the conquest of the swords in a way and therefore, facilitated the process of making Balkan lands Ottoman. However, their activities did not remained limited with these and also played a crucial role in making these lands Islamic towns in the period after the conquest with their activities.

\section{CONCLUSION AND COMPARATIVE EVALUATION}

The main objective of this study as mentioned before is to put forth the similarities and differences between activities of the dervishes, who were the reflections of Hodja Ahmed Yesevi in a sense, in the Islamization of Balkans process, and activities of public diplomacy, which is a modern concept. At first, the similar points will be discussed based on what was mentioned thus far.

As mentioned before, TiKA and Yunus Emre Institutes are the primary public diplomacy institutions of Turkey today. When the activities of these two institutions are compared with the activities of Yesevi dervishes, it may be observed that there are significant similarities between them. Since Hodja Ahmed Yesevi expressed his philosophies in Turkish, dervishes who followed his path carried on the same tradition. As a consequence of that, learning and popularization of Turkish were enabled in geographies where Turks did not live. Moreover, the fact that Yesevi's philosophies were read among the Turkish tribes on a wide geography, where Turkish was being spoken in different forms, made a significant contribution in conservation of the common texture of Turkish being spoken on aforementioned geography. Yunus Emre Institutes, which teach Turkish by setting up offices in more than forty countries, some in Turkish Republics and some in other countries, serve a similar outcome. On one hand they teach Turkish to people who speak other languages than Turkish, on the other hand they teach Turkish of Turkey to the Turks, who live in other countries where different forms of Turkish are 
being spoken, and therefore contribute to generating a common language. Moreover, besides teaching Turkish they are also organizing many events to promote Turkish Culture. Yesevi dervishes also carried out similar activities in lodges and zawiyahs. They were living models of Muslim Turkish culture primarily with their life styles, clothes, food culture and general attitudes. Furthermore, they promoted sportive activities such as archery and wrestling and cultural values they have in fields of art and literature, which emerged with Sufi Music, in these geographies.

There are great similarities between the activities of TiKA, which is another one of Turkey's significant institutions in the field of public diplomacy today, and services of Yesevi dervishes. TiKA is responsible for the organization of all foreign aids of Turkey, humanitarian aids being in the first place. Alongside all kinds of food, clothing and health material aids provided to the places in need all around the world, the institutions offer services in many fields such as drilling wells, building hospitals, providing technical education et cetera. Activities, which were carried out by dervishes centuries ago, were similar to these activities. By means of the foundations established with the income generated from the agricultural lands surrounding the lodges, all kinds of clothing and food requirements of the people in need were fulfilled. Besides, by means of the mills they and wells they drilled, they enabled the local population to benefit from these and therefore, met the water needs on dry lands. Dervishes, each of whom had a profession, helped the local population to gain similar skills by means of the activities they carried out. Moreover, some of the lodges functioned as a kind of hospital with the health services they offered.

TiKA and other institutions that carry out similar public diplomacy activities represent Turkey with the works they perform. Therefore, a sense of satisfaction is generated in people who live in aforementioned regions in consequence of the donations/activities performed. Actually, this is the primary expected result from public diplomacy activities. Despite the fact that Yesevi dervishes were not formal state officials, they represented Muslin Turkish nation in the eyes of non-Muslims living in Balkans. Therefore, all the positive activities they performed were considered a plus on behalf of aforementioned religion and her members. Thus, as mentioned before while this condition facilitated the conquest of Balkans by Ottomans, it also made a huge contribution in governing these land uneventfully thereafter.

There are significant differences between the activities of the dervishes and today's public diplomacy activities alongside with the similarities expressed up to this point. At this point here, it is necessary first and foremost to mention the differences in respect of objectives. The primary objective of the dervishes in Balkan lands was to communicate and expand Islam. Even the notion of conquest was subordinate to this objective. Thus, as it may be observed Sarı Saltık example, when the dervishes first came to these lands Ottoman State was not yet on stage as a state in the world. While a religious goal is being pursued in the activities of today's public diplomacy, the notion of conquest is beside the point. The objective at the present time is to generate sympathy on other societies and to ensure this sympathy is reflected on administrative levels. 
Another difference is regarding the methods and tools that were used. The developments experienced in almost every field technology being in the first place leads to important differences in case there are 5-8 centuries past in between. When dervishes use face-to-face or verbal communication, all the communication and transportation tools made available by technology today are being used in current public diplomacy activities.

In conclusion, it may be expressed although there are significant differences between activities of Yesevi dervishes and today's public diplomacy activities, it is determined that there are similarities in many points. In this context, while discussing the history of Turkish public diplomacy, it is possible to regard lodges as public diplomacy institutions and dervishes as public diplomacy actors. 


\title{
BALKANLARIN ISLAMLAŞMASINDAKI HOCA AHMED YESEVI ETKISINE KAMU DIPLOMASISi PERSPEKTIFINDEN BAKMAK
}

\begin{abstract}
ÖZET
Kamu diplomasisi kavramının literatürde kullanılmaya başlanmasının henüz yarım yüzyıllık bir geçmişi bulunmakla birlikte bu kavramla ifade edilen faaliyetlerin çok daha eski tarihlerden itibaren uygulandığı bilinmektedir. Kamu diplomasisindeki temel amaç başka toplumları etkilemektir. Bu amaç, kendinizin ve sahip olduğunuz değerlerin her türlü meşru kanalla karşı tarafa tanıtılması şeklinde gerçekleştirilmektedir. Bu bağlamda geçmişe bakıldığında, Hoca Ahmed Yesevi'nin faaliyetleri ile kamu diplomasisi uygulamaları arasında bir bağ kurmanın mümkün olduğu görülmektedir.
\end{abstract}

Türk İslam Dünyası'nda oldukça önemli bir şahsiyet olan Hoca Ahmed Yesevi, on binlerce mürit/derviş yetiştirerek onları Türkistan merkezli olarak doğu-batı, kuzey-güney hattında irşat misyonuyla görevlendirmiştir. Ağırlıklı olarak batıya yönelen bu dervişlerin gittikleri yerlerden biri de Balkan toprakları olmuştur. Henüz Balkan coğrafyasının İslam’la şereflenmediği bu dönemde söz konusu dervişler Hoca Ahmed Yesevi öğretisini buralara taşıyarak, bölgenin Türk İslam kültürü ile tanışmasına vesile olmuşlardır. Dervişler bu topraklarda kendilerine tekkeler kurmuş ve yaptıkları köprüler, inşa ettikleri değirmenler ve bunun gibi faaliyetlerle doğrudan halkla iç içe olmuş ve onlara hizmet etmişlerdir. Başta Sarı Saltık olmak üzere bu gelenekten yetişen dervişler örnek davranışları ile burada yaşayan halka model olmuş ve bu topraklarda islamiyet'in yayılmasında temel bir rol oynamışlardır.

Bu çalışmada Yesevi geleneğinden gelen dervişlerin Balkanların i̇slamlaşması bağlamındaki faaliyetleri kamu diplomasisi kavramı perspektifinden ele alınacaktır. Esasında modern bir kavram olan ancak uygulama örneklerine çok eski zamanlardan beri rastlanan kamu diplomasisi uygulamaları ile dervişlerin faaliyetleri arasındaki benzerliklere ve farklılıklara işaret edilecektir.

Anahtar Kelimeler: Kamu Diplomasisi, Hoca Ahmed Yesevi, Dervişler, Balkanlar, 


\section{REFERENCES}

Bakırcı, N. \& Türkan, H. K. (2013). “Tekke ve Zaviyelerin Balkanlar'daki Rolü ve Önemi”, Türük Dil, Edebiyat ve Halkbilimi Araştırmaları Dergisi, 1(1), 145-160.

Barkan, Ö. L. (2002). “Osmanlı İmparatorluğu’nda Kolonizatör Türk Dervişleri” Türkler Ansiklopedisi, Cilt 9, Ankara: Yeni Türkiye Yayınları.

Baş, E. (2011). “Ahmed Yesevî’nin Bektaşîlik, Alevîlik Üzerindeki Etkileri ve Osmanlı Dini Hayatındaki İzleri”, Ankara Üniversitesi İlahiyat Fakültesi Dergisi, 52(2), 21-53.

Bice, H. (2016). Pîr-i Türkistan Hoca Ahmed Yesevî, Ankara: Hoca Ahmet Yesevi Uluslararası Türk-Kazak Üniversitesi İnceleme-Araştırma Dizisi Yayın No: 33.

Çağ, G. (2012). "Osmanlıların Balkanları Fethinde İslam Kimliğinin Etkisi/Katkısı”, Çankırı Karatekin Üniversitesi Sosyal Bilimler Enstitüsü Dergisi, 3(2), 125-142.

Demirci, M. (1994). “Ahmed Yesevi'nin Yunus Emre'ye Tesiri Olmuş mudur?”, DEÜ ilahiyat Fakültesi Dergisi, (8), 61-84,

Fitzpatrick, K. R. (2010). The Future of U.S. Public Diplomacy: An Uncertain Fate, Leiden: Martinus Nijhoff Publishers.

Kencetay, D. (2012). “Hoca Ahmet Yesevî'nin Türk-İslâm Anlayışındaki Yeri”, Orta Asya'da İslam, Temsilden Fobiye, Ed. Muhammet Savaş Kafkasyalı, Ankara, Türkistan: Hoca Ahmet Yesevi Uluslararası Türk-Kazak Üniversitesi İnceleme- Araştırma Dizisi Yayın No: 12.

Nye, J. S. (2008). "Public Diplomacy and Soft Power", The ANNALS of the American Academy of Political and Social Science, 616, 94-109.

Ocak, A. Y. (2011). Sarı Saltık, Popüler İslam’ın Balkanlar'daki Destani Öncüsü (XIII. Yüzyıl), Ankara: Türk Tarih Kurumu Yayınları.

Özköse, K. (2003). "Anadolu'nun Türkleşmesi ve İslamlaşmasında Tasavvufî Zümre Ve Akımların Rolü", Cumhuriyet Üniversitesi İlahiyat Fakültesi Dergisi, 7(1), 249-279.

Pratkanis, A. (2009). "Public Diplomacy in International Conflicts. A Social Influence Analysis", Routledge Handbook of Public Diplomacy, Nancy Snow ve Philip M. Taylor (Ed.), London, New York: Routledge.,

Sancak, K. (2015). Dış Politikada Bir Etki Aracı Olarak Yumuşak Güç: Türkiye’nin Yumuşak Gücünün Analizi ve Azerbaycan Üzerindeki Yumuşak Güç Kapasitesinin Değerlendirilmesi, Karadeniz Teknik Üniversitesi Sosyal Bilimler Enstitüsü Yayınlanmamış Doktora Tezi.

Tuch, H. N. (1993). Communicating With the World: U.S. Public Diplomacy Overseas, New York: St. Martin's Press.

Tuğrul, T. (2014). “Sarı Saltık’ın Tarihî ve Menkıbevî Hayatı”. Türk Dünyası Bilgeler Zirvesi: Gönül Sultanları Buluşması. 26-28 Mayıs 2014. Eskişehir: Eskişehir 2013 Türk Dünyası Kültür Başkenti Ajansı (TDKB), 117-129.

Türk İşbirliği ve Koordinasyon Ajansı Başkanlığı (2014). “Türk İşbirliği ve Koordinasyon Ajansı Başkanlığı 2013 Faaliyet Raporu", http://store.tika.gov.tr/yayinlar/faaliyet-raporlari/faaliyet-raporu-2013.pdf, 
Üçüncü, K. (2006). “Anadolu ve Balkanların Fethi Sürecinde Türkmen Boylarının Hazar Ötesinden Taşıdığı Sözlü Kültürün İşlevi”, Türk Dünyası Araştırmaları, (165).

Yağmurlu, A. (2007). “Halkla Illişkiler Yöntemi Olarak Kamu Diplomasisi”, İletişim Araştırmaları Dergisi, 5(1), 938.

Yediyıldız, M. “Türkiye'nin Kültürel Diplomasi Ayağı, Yumuşak Gücü: Yunus Emre Enstitüsü”, http://www.yeniturkiye.org/turkiyenin-kulturel-diplomasi-ayagi-yumusak-gucu-yunus-emre-enstitusu/ yeni-akimlar/14227, (14/07/2016)

Yıldırım, A. (2012). “Orta Asya'da İslâmî İlimlerin Ortaya Çıkışı ve Gelişimi”, Orta Asya'da İslam, Temsilden Fobiye, Ed. Muhammet Savaş Kafkasyalı, Ankara, Türkistan: Hoca Ahmet Yesevi Uluslararası Türk-Kazak Üniversitesi İnceleme- Araştırma Dizisi, Yayın No: 12.

Yıldız, M. (2015). “Takriz”, Ahmed Yesevi, Ed. Necdet Tosun, Ankara: Hoca Ahmet Yesevi Uluslararası Türk-Kazak Üniversitesi İnceleme Araştırma Dizisi, Yayın No: 23.

Yılmaz, S. (2012). Akıllı Güç, İstanbul: Kum Saati Yayınları. 